\title{
ABD’nin Irak Müdahalesinde Güvenliğin Özelleşmesi: Sözleşmeli Personel ve Özel Askeri ve Güvenlik Şirketlerinin Rolü ve Etkileri
}

\author{
Privatization of Security in Iraq with Us Intervention: The Role and Effects of Contracted \\ Personnel and Private Military and Security Companies
}

\section{Turan Çağlar ${ }^{1}$ (i)}

Öz

ABD’nin 2003 yılında Irak’a müdahalesi ile birlikte özel askeri ve güvenlik şirketleri, ABD’nin en önemli ortaklarından biri olmuş ve hatta sözleşmeli personel, Irak'ta koalisyon güçleri içerisinde ABD'den sonraki en büyük grup haline gelmiştir. 2003 yılı sonrası ABD yönetimleri, Irak Savaşı'nın artan ekonomik, insani ve siyasi maliyetlerini sözleşmeli personel üzerinden dışsallaştırmaya çalışmıştır. 2011 yılı öncesi Irak'ta ABD askerlerinin yanında yer alan sözleşmeli personel, 2011 yılı sonrası ABD askerlerinin yerine görev almaya başlamıştır. ABD yönetimleri, özel şirketler aracılığıyla bazı maliyetleri dışsallaştırabilse de sözleşmeli personelin insan hakları ihlalleri, ABD’nin Irak ve bölgedeki ününe zarar vermiştir. Sözleşmeli personel ayrıca Irak'ta şiddet uygulayan ve şiddete maruz kalan aktörlerin başında gelmiş ve ülke içerisindeki şiddetin yükselmesinde rol oynamıştı. Irak'ta ABD aracılığıyla güvenliğin özelleşmesi ise Irak'taki güvenlik kavramını dönüştürmüştür. Özel askeri ve güvenlik şirketleri ve çalışanlarının hukuki statüleri ve denetimleri, güvenlik kavramının dışlayıcı bir hale gelmesi ve güvenliğin piyasalaşması, Irak gibi kırılgan bir ülkede yeni güvenlik sorunlarına yol açmıştır. Özel askeri ve güvenlik şirketlerinin Irak Savaşı boyunca oynadığı roller ise geleneksel güvenlik anlayışı ve şiddet kullanma tekelinin devriyle ilgili Uluslararası Illişkilerde yeni tartışmalara sebep olmuştur.

\section{Anahtar Kelimeler}

Özel askeri ve güvenlik şirketleri, Sözleşmeli personel, ABD, Irak, Irak Savaşı

\begin{abstract}
With the US intervention in Iraq in 2003, private military and security companies (PMSCs) became one of the most important partners of the United States and contractor personnel even became the second largest group within the coalition forces. After 2003, US administrations tried to externalize the increasing economic, humanitarian and political costs of the Iraq War through contractor personnel. While the contracted personnel fought in Iraq alongside the US forces before 2011, they replaced the US forces in the country after 2011. Although US administrations could offload some of the burden of their work through the PMSCs and their contracted personnel, human rights violations of contracted personnel undermined the reputation of the US in Iraq and the region. Contractor personnel also became a part of the increasing violence in Iraq as they themselves became targets and responded in turn and thus they became an important party of the increasing violence in the country. The privatization of security in Iraq through the US also transformed the concept of security and caused new security problems that are still being discussed. The legal status of and control over the PMSCs and their personnel, the exclusionary understanding about security and the marketization of security led to new security problems in Iraq, which was becoming an increasingly fragile country. The roles played by the PMSCs during the Iraq War also led to new theoretical and practical discussions in International Relations regarding the transformation of traditional security understanding and the monopoly on force.
\end{abstract}

\section{Keywords}

Private military and security companies, Contractor personnel, USA, Iraq, Iraq War

1 Sorumlu Yazar: M. Turan Çağlar (Arş. Gör.), FMV Işık Üniversitesi, İktisadi ve İdari Bilimler Fakültesi, Uluslararası İlişkiler Bölümü, Meşrutiyet Mahallesi, İstanbul, Türkiye. E-posta: turan.caglar@isikun.edu.tr ORCID: 0000-0003-1906-1471

Attf: Caglar, M. T. (2020). ABD’nin Irak müdahalesinde güvenliğin özelleşmesi: Sözleşmeli personel ve özel askeri ve güvenlik şirketlerinin rolü ve etkileri. SiYASAL: Journal of Political Sciences, 29(1), 143-163. http://doi.org/10.26650/ siyasal.2020.29.1.0027 


\section{Extended Summary}

The US military intervention in Iraq in 2003 led to new and important debates in terms of international relations. The benefits and harmful effects of private military and security companies (PMSCs) and their contracted personnel after 2003 gave rise to new discussions about US intervention in particular and the concept of security in general. The economic, humanitarian and political costs of the war during the US presence in Iraq increased each year. The economic cost of the Iraq war in 2008 was around 197 billion dollars, while the number of US troops in the country increased to 161,783 in the same year. In 2008, 63\% of US public opinion regarded the military intervention in Iraq to be wrong. The increasing economic, humanitarian and political costs of the US during the post-2003 period have made the externalization of the burdens of this war significant, and the PMSCs and their contracted personnel have become prominent in this process. The Bush administration tried to externalize the rising costs of war by deploying an increasing number of contracted personnel in Iraq. Thanks to the PMSCs, a large number of contracted personnel were able to work in Iraq thereby reducing the cost, and contractor personnel even became the second largest group within the coalition forces. Moreover, with the increasing number of foreign and Iraqi contractors, the US could lower their casualties and in this way, the Bush administration externalized the humanitarian costs of the war. By externalizing the economic and humanitarian burdens of the war, the US administration tried to limit the reaction of the US public. Moreover, limited congress control over the contracted personnel also helped to externalize the political costs for the Bush administration. Although the Obama and Trump administrations have avoided costly military interventions, the PMSCs during these periods have continued to protect US interests in Iraq. After the Bush administration, the contractors replaced the US forces in Iraq and they are still operating in the country.

Although contracted personnel helped externalize some costs, problems caused by them resulted in new costs both for the US and Iraq. Both unauthorized use of force and human rights violations by contracted personnel undermined the US reputation in Iraq and strengthened antiUS trends within the country. Furthermore, issues such as coordination problems between the US forces and private companies in the conflict zones created additional costs for the US during the war. The PMSCs became an active party of the war in Iraq and they directly or indirectly affected the level of violence. The limited accountability of the contracted personnel in terms of national and international laws made the control of these companies an important issue, while the privatization of the security understanding via PMSCs led to the transformation of the concept of security in Iraq. Changing the wages of the contractors according to the level of violence in Iraq and the nationality of the contractors accelerated the marketization of security. While the privatization of security weakened the concept of public security, security in Iraq turned into a service that can be purchased. Although various regulatory mechanisms have been developed to prevent the problems caused by the PMSCs, it is not easy to operate these mechanisms in a fragile country like Iraq.

The involvement of the PMSCs in an international military intervention has also raised new questions about international security. Deliberate outsourcing of military functions to private companies by states has led to new debates about both the state monopoly on force and the changing understanding of traditional security. The solutions to the new problems created by top-down privatization and its relations with the bottom-up privatization maintain their theoretical and practical importance and will continue to be important issues in International Relations, International Law and Security Studies. 


\section{ABD’nin Irak Müdahalesinde Güvenliğin Özelleşmesi: Sözleşmeli Personel ve Özel Askeri ve Güvenlik Şirketlerinin Rolü ve Etkileri}

9/11 saldırıları sonrası ABD’nin ulusal ve uluslararası düzlemlerde hayata geçirdiği siyasalar, yeni hukuki ve normatif tartışmaları da beraberinde getirmiştir. 9/11 saldırıları sonrası Kasım 2001'de yürürlüğe giren Vatanseverlik Yasası ile yürütmenin yetkileri arttırılmış, yabancıların gizli ve süresiz tutukluluğuna varacak olağanüstü hükümler getirilmiş ve olağanüstü askeri mahkemelerin kurulmasının önü açılmıştır (Albayrak, 2013: 9). Vatanseverlik yasasının getirdiği demokratik olmayan uygulamalar, ABD siyasetinde önemli bir tartışma konusu olurken ABD'nin Afganistan ve Irak'a müdahaleleri uluslararası ilişkiler açısından yeni kırılmalara yol açmıştır. Özellikle Irak'a askeri müdahalenin hukuki temelleri ve BM ve NATO gibi uluslararası örgütlerin bu müdahaleye tepkileri, savaş açma hakkı (jus ad bellum) ve savaşın adil idaresi (jus in bello) açısından önemli tartışma konuları olmuştur.

Bush yönetimi, caydırıcılık gibi Soğuk Savaş döneminden kalan tedbirlerin 'terörizm' gibi yeni tehditlere karşın etkin olamayacağını savunarak önleyici savaş doktrinini devreye sokmuş (Jervis, 2009: 2005) ve önleyici savaş çerçevesinde askeri müdahalelere hukuki bir zemin bulmaya çalışmıştır. Fakat BM yetkilendirmesi olmaksızın Irak’a yapılan askeri müdahale hukuk dışı görülmüştür. BM yetkilendirmesinin olmamasının yanında Irak özelinde saldırı tehdidin belirgin olmaması, ön alıcı ve öncelenmiş meşru müdafaa hakkının uygulanmasını da hukuken sakıncalı bir hale getirmiştir (Simpson, 2005: 172). Irak'a düzenlenen askeri müdahalenin hukuki temellerinin zayıf olmasıysa uluslararası ve bölgesel örgütlerin tepkisine sebep olmuştur. Bu tepkiler bağlamında örneğin dönemin BM Genel Sekreteri, ABD’nin Irak'a müdahalesinin BM şartına aykırı olduğunu belirtirken bu müdahaleyi hukuk dışı olarak tanımlamıştır (MacAskill \& Borger, 16 Eylül 2004). Küresel örgütün yanı sıra ABD’nin öncülügünü yaptığı NATO'nun Almanya ve Fransa gibi üyeleri bile bu askeri operasyona tepki göstermiş (The Guardian, 22 Ocak 2003) ve bu tepkiler sonucunda NATO, kurumsal olarak ABD'nin Irak'taki operasyonlarının yürütülmesinde yer almamıştır (NATO, 1 Eylül 2015).

ABD’nin Irak ve Afganistan'a düzenlediği müdahalelerin normatif boyutları, hukuki zemini ve gerekçeleri kadar zaman içerisinde bu iki ülkede hayata geçirdiği siyasalar ve bu savaşların idaresi de önemli tartışmalara yol açmıştır. Irak ve Afganistan'a yapılacak müdahalelerin askeri hazırlıkları tamamlanana kadar $\mathrm{ABD}$, yerel güçlerle işbirliğine gitmiş, fakat ABD’nin Irak ve Afganistan'da silahlı devlet dışı aktörleri kullanması yeni tartışmalara sebep olmuştur. ABD’nin Afganistan'da yerel güçlerin oluşturduğu Kuzey İttifakı'nı, Irak'ta ise Peşmerge güçlerini çatışma sahalarında kullanması (Peltier, 2005: 3), silahlı devlet dışı aktörlerin devletler arası savaşlardaki rolü ve ilerleyen yıllarda iç savaştaki rolleri konusunda yeni itirazlara sebep olmuştur. ABD’nin teröre karşı savaşta zamanla daha sık kullanmaya başladığı silahlı insansız hava araçları (SİHA) saldırıları ve bu saldırıların sebep olduğu sivil ölümleri de ABD’nin araçlarına karşı önemli itirazlara sebep olmuştur (The Bureau of Investigative Journalism, n.d.). Bush döneminde SİHA'ların yoğun bir şekilde kullanıldığ Obama döneminde daha da genişletilmiş ve yüksek öncelikli terör hedeflerinin yanında orta ve düşük öncelikli hedeflere karşı da yoğun saldırılar düzenlenmeye başlanmıştır. Fakat hedef alarak öldürme programının genişletilmesi, ABD’ye karşı hukuki, artan 
sivil ölümleri ise normatif eleştirilere sebep olmuştur (Albayrak, 2013: 106). ABD’nin 9/11 sonrası Afganistan ve Irak’ta zamanla devreye soktuğu bir diğer önemli araç, özel askeri ve güvenlik şirketleri olmuştur. Bu şirketlerin Irak'taki kullanımı ise uluslararası hukuk, uluslararası insancıl hukuk, Irak iç savaşı, Irak’ta güvenliğin piyasalaşması ve özel şirketlerin Irak’taki gelişmelere etkisi açısından yeni tartışmalara yol açmıştır.

ABD’nin Irak’taki savaşının zamanla artan maliyetleri önemli bir sorun olmaya başlamış ve savaşın artan maliyetlerini azaltmak ve dişsallaştırmak için Bush yönetimi, özel askeri ve güvenlik şirketlerini ve bu şirketler aracılığıyla sağlanan sözleşmeli personeli (contractor personnel) $)^{1}$ devreye sokmuştur. Özel askeri ve güvenlik şirketleri aracılığıyla ABD yönetimi; ulaşım, inşaat ve temel destek, istihbarat analizi, çeviri, tercüme ve özel güvenlik ${ }^{2}$ alanlarında (Peters \& Palagais, 2019: 1) on binlerce sözleşmeli personeli Irak’ta konuşlandırabilmiş ve bu yolla Irak Savaşı'nın belirli maliyetlerini dışsallaştırabilmiştir. Bush sonrası dönemde de savaşın maliyetleri ABD açısından önemini korumaya devam ederken özel askeri ve güvenlik şirketleri Irak’taki mevcudiyetini korumuştur (Krieg, 2016: 98-99). Özel askeri ve güvenlik şirketleriyle birlikte ABD, Irak’ta savaşın bazı maliyetlerini dışsallaştırabilse de bu şirketlerin sebep olduğu sorunlar, ABD açısından yeni ve uzun vadeli maliyetlere sebep olmuştur. Bu yüzden $A B D$, özel şirketler aracılığıyla Irak savaşının askeri, insani ve ekonomik maliyetlerini düşürse de bölgedeki ününe ve Irak siyasetine zarar vermiştir. Ayrıca özel askeri ve güvenlik şirketlerinin kullanımı, uluslararası alanda önemli bir konu olmaya devam ederken Irak'ta güvenliğin ABD eliyle özelleştirilmesi, Irak açısından yeni sorunlara yol açmıştır.

$\mathrm{Bu}$ bilgiler 1şı̆̆ında çalışmanın temel sorusu; ABD’nin özel askeri ve güvenlik şirketleri ile bu şirketler üzerinden temin edinen sözleşmeli personeli Irak'ta neden ve nasıl kullandığıdır? Bu temel sorunun yanında ABD’nin özel askeri ve güvenlik şirketleri aracılığıyla savaşın hangi maliyetlerini dışsallaştırabildiği, bu şirketlerin Irak'ta hangi sorunlara sebep olduğu ve bu sorunların hangi açılardan ABD ve Irak'a zarar verdiği aydınlatılmaya çalışılacaktır. Bu sorulara aranacak cevaplarla ayrıca Irak’ta güvenlik kavramının dönüşümü gösterilecektir. Bu temel sorular çerçevesinde çalışma üç temel bölümden oluşmaktadır. İlk bölümde kavramsal olarak güvenliğin özelleşmesi ve özel askeri ve güvenlik şirketlerinin özelleşmedeki rolleri gösterilecektir. İkinci bölümde ABD’nin Irak Savaşı boyunca ortaya çıkan maliyetleri ve özel askeri ve güvenlik şirketleri

1 ABD federal yönetmelikler kanununa göre sözleşmeli personel (contractor personnel) tanımı, ABD’nin savunma bakanlığı ile sözleşme ilişkisine sahip herhangi bir şahıs, firma, şirket veya ortaklık için kullanılmaktadır. Sözleşmeliler, savunma bakanlığının mal ve hizmet satın almak için sözleşme imzaladığı özel şirketleri veya özel şirketler üzerinden sağlanan ve belirli görevleri yerine getirmek için sözleşme imzalanan kişileri tanımlamaktadır. Sözleşmeli personel tanımı, savunma bakanlığı bünyesinde bulunan ordu mensubu veya sivil kariyer memurları için kullanılmaz. bkz: Peters, H. M., \& Plagakis, S. (2019). Department of defense contractor and troop levels in Iraq and Afghanistan: 2007-2018. Washington, the USA: Congressional Research Service, 1.

2 ABD kongresinin araştırma raporunda özel güvenlik personeli (private security contractor personnel); çevirmenlik, taşıma, iletişim veya eğitim gibi diğer alanlarda faaliyet gösteren sözleşmeli personelden (private contractor personel) farklı gösterilmektedir. Özel güvenlik personelinin faaliyet alanları; belirli mekanların korunması, konvoy güvenliği sağlama, güvenlik konvoyu oluşturma ve askeri eğitim ile sınırlandırılmıştır. Tanımlama için bkz: Peters, H. M., \& Plagakis, S. (2019). Department of defense contractor and troop levels in Iraq and Afghanistan: 2007-2018. Washington, the USA: Congressional Research Service, 4. Bu şirketlerde görev alanlar için kapsayıcılığı sağlamak adına genel tanım olarak 'sözleşmeli personel' tanımı kullanılacaktır. Özel güvenlik alanındaki sözleşmeli personelin ayrı bir şekilde vurgulandığı yerlerde ise ‘özel güvenlik personeli’ tanımı kullanılacaktır. 
aracılığıyla hangi maliyetlerin dışsallaştırılabildiği gösterilecektir. Üçüncü bölümde ise özel askeri ve güvenlik şirketlerinin $A B D$ ve Irak açısından yarattığı sorunlar ve yeni maliyetler aydınlatılacaktır. Bu bölümde ayrıca Irak özelinde yaşanan gelişmelerin güvenlik kavramına etkileri analiz edilecektir.

\section{Kuramsal Çerçeve: Güvenliğin Özelleşmesi}

Geleneksel anlamda şiddet kullanma tekeline sahip olma modern ulus-devletin en önemli özelliklerinden biri olarak görülürken (Welch, 2009: 353) askeri ve güvenlik hizmetlerinin özelleşmesi, devletlerin şiddet kullanma tekelinden vazgeçmeleri olarak tanımlanmaktadır (Wulf, 2005: 36). Bir başka deyişle şiddetin özelleşmesi, devletlerin 'doğas1 gereği' (Palou-Loverdos \& Armendariz, 2011: 16) sahip olduğu şiddet kullanma tekelini başka aktörlere devretmesidir. Devletlerin şiddet kullanma tekelinden vazgeçmeleri ise gönülsüz olabileceği gibi gönüllü de olabilmektedir. Devletlerin gönüllü bir şekilde bu tekelden vazgeçmeleri, gücün veya şiddetin yukarıdan aşağıya doğru özelleşmesi şeklinde tanımlanmaktadır. Yukarıdan aşağıya özelleşme, devletler/ hükümetler tarafindan planlanan ve uygulanan bir özelleşme şekli olup (Mandel, 2001: 136-138), bu özelleşme ile geleneksel askeri ve güvenlik görevleri, özel girişimlere devredilmektedir. ${ }^{3}$

Askeri ve güvenlik görevlerinin özel girişimlere devrinde farklı şekilde sınıflandırılabilecek özel şirketler ön plana çıkmaktadır. En tipik ayrım özel güvenlik şirketleri (private security companies-PSCs) ile özel askeri şirketleri (private military companies-PMCs) arasında yapılmaktadır. Büyük metropollerde güvenliği sağlayan şirketler, özel güvenlik şirketlerinin en tipik örneği olarak gösterilirken bu şirketler, iç güvenlik konusunda yasaların ve düzenin devamını sağlamaya yardımcı olan şirketlerdir. Özel askeri şirketleri ise devletlerin silahlı kuvvetlerinin üstlendiği görevleri üstlenme potansiyeline sahip olan şirketlerdir (Wulf, 2005: 49). Bu şirketler, askeri eğitim ve askeri operasyonlara yönelik hizmetler gibi daha aktif güvenlik hizmeti sağlamaktadır (Brooks, 2000: 129-130). Özel askeri şirketler, özellikle çatışma sahasına yakınlıkları ve sağladıkları hizmetler açısından da farklılaşmaktadır. 'Askeri hizmet sağlayıcı' şirketler, çatışma sahasına en yakın olan ve doğrudan çatışmalarda yer alabilen şirketler olarak görülmektedir (Abrahamsen \& Williams, 2007: 135). Askeri hizmet sağlayıcı şirketlerin dışında 'askeri danışmanlık' ve 'askeri destek sağlayan şirketler' de tablo 1'de gösterildiği üzere özel askeri şirketlerin parçaları olarak tanımlanmaktadır. Askeri danışmanlık şirketleri, danışmanlık ve eğitim hizmetleri sağlarken (Ekmekçioğlu, 2016: 87-88) askeri destek sağlayan şirketler ise teknik destek ve lojistik gibi ek hizmetleri müşterilerine sunmaktadır (Singer, 2002: 201). Özel güvenlik şirketleri ile özel askeri şirketler arasında yapılan ayrımların yanında geleneksel anlamda askeri-endüstriyel kompleksin parçası olarak görülen ve silahlı kuvvetler için silah ve ekipman üreten 'savunma üreticisi şirketler’ ile askeri üslere malzeme tedariki sağlayan, üniforma üreten, askeri personel ve

3 Şiddetin aşağıdan yukarı özelleşmesi, hukuk dışı özelleşme olarak tanımlanmaktadır. Bu tip bir özelleşme, devlet dışı aktörlerin siyasi ve ekonomik kazanç sağlamaları amacıyla şiddete başvurmaları sonucu ortaya çıkar. Aşağıdan yukarıya özelleşmeye örnek aktörler olarak çeteler, ayrılıkçı hareketler, savaş lordları, organize suç örgütleri, isyancılar, milis güçleri ve paralı askerler gösterilmektedir. Aşağıdan yukarı ve yukarıdan aşağıya özelleşmeyle ilgili ayrıntılı bilgi için bkz: Wulf, H. (2011). The Privatization of violence: a challenge to state-building and the monopoly on force. The Brown Journal of World Affairs, 18(1), 137 149. 
aileleri için yaşam alanlarının oluşturulmasından üslerin inşasına kadar çeşitli hizmetleri sağlayan 'hizmet sağlayıcı şirketler', güvenliğin özelleşmesi sürecinde ortaya çıkan diğer aktörler olarak tanımlanmaktadır (Wulf, 2005: 49). Özel güvenlik şirketlerinin, hizmet sağlayıcı şirketlerin ve savunma üreticisi şirketlerin hukuki statüleri çok daha belirgin olmakla birlikte özel askeri şirketlerin özellikle güç kullanımı açısından ulusal ve uluslararası alanlarda hukuki statüleri, 2003 yılı sonrası dönemde önemli tartışma konularından biri olmuştur. ${ }^{4}$

Tablo 1

Özel Askeri ve Güvenlik Şirketlerinin Sinıflandırılması

\begin{tabular}{|c|c|c|}
\hline \multicolumn{3}{|c|}{ Özel Askeri ve Güvenlik Şirketleri } \\
\hline Şirket Türü & Hizmet Türü & Sağlanan Hizmetler \\
\hline \multirow{7}{*}{ 1. Özel Güvenlik Şirketleri } & \multirow{4}{*}{ Mülkiyet koruması } & Koruma ve gözetim \\
\hline & & Fabrikaları, madenleri vb. koruma \\
\hline & & Yerel devriye ve koruma \\
\hline & & $\begin{array}{l}\text { Kamusal alanlarda (metro, alışveriş merkezleri } \\
\text { vb.) düzen ve kanunların korunması }\end{array}$ \\
\hline & \multirow{3}{*}{$\begin{array}{l}\text { Suçla mücadele ve suçun } \\
\text { önlenmesi }\end{array}$} & Adam kaçırmayla mücadele \\
\hline & & Cezaevlerinin yönetimi \\
\hline & & Soruşturma ve istihbarat toplama \\
\hline \multirow{4}{*}{$\begin{array}{l}\text { 2. Savunma Üreticisi } \\
\text { Şirketler }\end{array}$} & \multirow{2}{*}{ Silah ve ekipman üretimi } & Araştırma ve geliştirme \\
\hline & & Üretim \\
\hline & \multirow{2}{*}{ Askeri destek ve yardım } & Askeri eğitim \\
\hline & & Silah ve bileşenlerinin İhracatı \\
\hline \multirow{4}{*}{ 3. Hizmet Sağlayıcı Şirketler } & \multirow{3}{*}{ Askeri tesislerin yönetimi } & Araç filosu yönetimi \\
\hline & & Kantin yönetimi \\
\hline & & Askeri üslerin inşası ve yönetimi \\
\hline & Finansman & Askeri projeler ve silah ve ekipman tedariki \\
\hline \multicolumn{3}{|l|}{ 4. Özel Askeri Şirketler } \\
\hline \multirow{5}{*}{$\begin{array}{l}\text { a. Askeri Hizmet Sağlayan } \\
\text { Şirketler }\end{array}$} & \multirow{4}{*}{$\begin{array}{l}\text { Barışı koruma ve } \\
\text { insani yardım }\end{array}$} & Barışı koruma için lojistik \\
\hline & & $\begin{array}{l}\text { Silahsızlanma, mayın temizleme, silah toplama } \\
\text { ve imha }\end{array}$ \\
\hline & & $\begin{array}{l}\text { Karmaşık acil durumlarda lojistik ve ulus inşası } \\
\text { programları }\end{array}$ \\
\hline & & $\begin{array}{l}\text { Konvoyların, mültecilerin ve toplulukların } \\
\text { korunması }\end{array}$ \\
\hline & Çatışma ve savaş & Silahlı mücadele \\
\hline
\end{tabular}

4 Özel askeri ve güvenlik şirketlerinin çalışanları, paralı askerler ile karıştırılmaktadır. Uluslararası sözleşmelerle paralı askerlik yasaklanmışken özel askeri ve güvenlik şirketleri, ilgili devletler tarafından görevlendirildikleri için bu şirketlerin çalışanları hukuki olarak paralı askerlerden farklıdır. Kavram karmaşasına sebep olan ise tıpkı Irak ve Afganistan'da olduğu gibi özel askeri ve güvenlik şirketlerinin ulus ötesi bölgelerde kullanılması ve şirket çalışanlarının yetkileri dışında şiddete başvurmalarından kaynaklanmaktadır. Fakat hukuki tanımlamalarda paralı askerlik tanımlaması ile özel askeri ve güvenlik şirketi çalışanlarının faaliyetlerinin kesiştiği görülmektedir. Paralı askerlik tanımının özel güvenlik çalıșanlarıyla farklılaşması için zaman içerisinde paralı askerliğin tanımının dönüștüğü görülmektedir. Paralı askerlik tanımında yaşanan hukuki dönüşüm için bkz: Krahmann, E. (2012). from 'mercenaries' to 'private security contractors': the (re)construction of armed security providers in international legal discourses. Millennium-Journal of International Studies, 40(2), 343-363. 


\begin{tabular}{|l|l|l|}
\hline \multirow{3}{*}{$\begin{array}{l}\text { b. Askeri Danışmanlık } \\
\text { Sağlayan Şirketler }\end{array}$} & Danışmanlık ve planlama & $\begin{array}{l}\text { Tehdit/risk analizi, strateji geliştirme, silahlı } \\
\text { kuvvetler için danışmanlık }\end{array}$ \\
\cline { 2 - 3 } & Eğitim & $\begin{array}{l}\text { Askeri eğitim, silah eğitimi, özel kuvvetler } \\
\text { eğitimi, dil eğitimi ve psikolojik savaş }\end{array}$ \\
\hline \multirow{4}{*}{$\begin{array}{l}\text { c. Askeri Destek Sağlayan } \\
\text { Şirketler }\end{array}$} & Lojistik ve destek & $\begin{array}{l}\text { Acil durumlarda ve savaşta lojistik sağlama } \\
\text { Mayın temizleme, muhariplerin yeniden ente- } \\
\text { grasyonu }\end{array}$ \\
\cline { 3 - 3 } & $\begin{array}{l}\text { Mülteci kamplarının inşası ve yönetimi, mül- } \\
\text { tecilerin yeniden entegrasyonu }\end{array}$ \\
\cline { 2 - 3 } & $\begin{array}{l}\text { Teknik hizmetler, hava kontrolü, istihbarat } \\
\text { toplama, IT hizmetleri }\end{array}$ \\
\cline { 2 - 3 } & $\begin{array}{l}\text { Teknik servis ve } \\
\text { onarımlar }\end{array}$ & Silah ve ekipman onarımı \\
\hline
\end{tabular}

Wulf, H. (2005). Internationalizing and privatizing war and peace. Hampshire, England: Palgrave Macmillan, 4347. Singer, P.W. (2002). Corporate warriors: the rise of the privatized military industry and its ramifications for international security. International Security, 26(3), 200-202.

Çalışma boyunca yukarıdan aşağıya şiddetin özelleşmesinde ortaya çıkan tüm aktörleri kapsamak için ‘özel askeri ve güvenlik şirketi’ (Private Military and Security Companies-PMSCs) tanım olarak kullanılacaktır. Kavramsal olarak özel askeri şirketler ile özel güvenlik şirketleri arasında ayrım yapılsa da hem genel olarak hem de Irak pratiğinde bu tip bir ayrım sağlıklı görülmemektedir. Tablo 1'de görüldüğü üzere bazı hizmetler, farklı şirket tipleri tarafından sağlanabilmektedir. Bu bağlamda örneğin silahlı ve güvenlik güçlerinin eğitimi, özel askeri şirketlerin faaliyetleri olduğu kadar savunma üreticisi şirketlerin faaliyetleri içerisinde de görülebilir. Benzer şekilde silah ve askeri ekipman üretim ve onarımı da özel askeri şirketlerin yanı sıra hizmet sağlayan şirketlerin faaliyetleri içerisinde görülmektedir. Irak özelinde incelendiğinde ise Irak’ta yer alan şirketler, kendilerini özel güvenlik şirketi, yani savunma temelli şirket olarak tanımlasalar da bu şirketler, Irak’ta savunmanın ötesinde saldırı temelli eylemlerde de bulunduğu için özel askeri şirket olarak da tanımlanabilirler. Ayrıca çatışma alanlarında şiddet kullanımıyla da ilişkili olarak savunma ve saldırı faaliyetleri birbirine karışmakta ve 'güvenlik' ve 'askeri' kavramları iç içe geçmektedir (Avant \& Sigelman, 2010: 232). Savunma-saldırı ayrımının sağlıklı olmamasının dışında Irak’taki özel askeri ve güvenlik şirketlerinin birden fazla alanda özel şirket faaliyetinde bulunduğu görülmektedir (Percy, 2012: 942). Bu yüzden literatürde de sıkça kullanılan özel askeri ve güvenlik şirketi tanımı (Erkmen, 2019: 5), Irak'ta faaliyet gösteren tüm şirketleri kapsaması açısından daha kullanışlı bir tanım olarak ön plana çıkmaktadır. Bu yolla ayrıca 'savunma üreten şirketler' ve 'servis sağlayan şirketler' de analiz içerisinde gösterilebilecektir.

\section{Özel Askeri ve Güvenlik Şirketleri ve Sözleşmeli Personel Aracılığıyla Savaşın Maliyetlerinin Azaltılması}

ABD’nin Afganistan'ın yanında Irak'a yaptığı askeri müdahale uzadıkça bu savaşlar, ABD’ye önemli ekonomik, insani ve siyasi maliyetler yaratmış ve bu maliyetlerin paylaşılması, ABD yönetimleri açısından önem kazanmıştır. Bush döneminde Afganistan ve Irak’taki savaşlar, yaklaşık 1,5 trilyon dolara mal olurken bütün bu süreç zarfında terörle mücadeleye 5 trilyon dolara yakın bir para harcanmıştır (Nuruzzaman, 2015: 176). Bu savaşların ekonomik maliyetlerinin yanında ABD açısından 6 bin ölü ve 40 bin yaralıya mal olması, on binlerce Afganlı ve Iraklının ölmesi (Mearsheimer, 2011: 17), 
yaklaşı 1,7 milyon Iraklının ülke içinde yer değiştirmesi ve 2 milyon Iraklının Irak'tan kaçması, bu savaşların insani ve siyasi maliyetlerini arttıran önemli etkenler olmuştur. Irak ve Afganistan'a yapılan askeri müdahalelerin Bush yönetimine yarattığı maliyetlerinin her geçen yıl artması, özel askeri ve güvenlik şirketleri aracılığıyla sözleşmeli personelin devreye sokulmasına sebep olmuştur. ABD yönetimleri, sözleşmeli personel yoluyla savaşın belirli maliyetlerini dışsallaştırılmaya çalışılmıştır. Bush döneminde savaşın artan maliyetlerinin etkisi Obama yönetimini kamuoyundan uzak ve daha az maliyetli askeri araçların kullanılması stratejisine itmiştir. Bu şartlar altında Bush ve Obama'nın Irak'a yaklaşımlarından bağımsız olarak her iki başkan için özel askeri ve güvenlik şirketleri, ABD açısından savaşın maliyetlerinin paylaşılması noktasında önemini korumaya devam etmiştir. Benzer bir durum Trump döneminde de devam etmiş ve Irak'tan çekilmiş olmasına rağmen $\mathrm{ABD}$, Irak'taki faaliyetlerini genellikle sözleşmeli personel üzerinden devam ettirmiş̧ir. Farklı ABD yönetimlerinin Irak’taki savaşın maliyetlerini dışsallaştırmak için özel askeri ve güvenlik şirketlerini yoğun bir şekilde kullanması sonucunda 2003 Irak Savaşı, askeri şirketlerin gelmiş geçmiş en yoğun kullanıldığ savaş olmuştur (Tangör \& Yalçınkaya, 2010: 137). ABD'nin Irak'ta bulunduğu süre zarfinda ortaya çıkan ve önemli tartışmalar yaratan maliyetleri kabaca ekonomik, insani ve siyasi maliyetler olarak sınıflandırılabilir. ABD yönetimleri, sözleşmeli personel aracılığıyla bu maliyetleri ortadan kaldıramasa da dışsallaştırmaya ve belirli ölçülerde düşürmeye çalışmıştır.

\section{Ekonomik Maliyetlerin Dışsallaştırılması}

2003-2016 yılları arasında ABD, Irak Savaşı'na yaklaşık 1.060 milyar dolar harcarken bu miktarın 748 milyar doları, 2003-2009 yıllarında Bush yönetimi tarafından harcanmıştır. Irak'taki savaşın ABD'ye maliyeti 2003 ve 2004 yıllarında yıl başına yaklaşık 90 milyar dolarken, bu miktar 2005 yılında 105 milyar, 2006 yılında ise 108 milyar dolar civarına ulaşmıştır. Özellikle Irak'taki ayaklanmanın görünür olduğu 2007-2008 yıllarında savaşın ekonomik maliyetleri yükselmiş ve bu maliyet, 2007 yılında yaklaşı 156 milyar dolara, 2008 yılındaysa 197 milyar dolara yükselmiştir (Amadeo, 2019). Obama yönetiminde ABD'nin Irak'tan çekilmesiyle birlikte Irak'taki savaşın ekonomik maliyetleri azalsa da özellikle Irak Şam İslam Devleti'ne (IŞiD) karşı Irak ordusunun eğitimi amacıyla yapılan askeri yardımlar, yeni ekonomik maliyetlere yol açmıştır. Bu şartlar altında gerek ABD'nin Irak'ta bulunduğu süre zarfinda gerekse 2011 yılı sonrası dönemde oluşan ekonomik maliyetler, özel askeri ve güvenlik şirketleri aracılığı ile dışsallaştırılmaya çalışılmıştır. Toplam maliyete kıyasla küçük sözleşmeler karşıllığında $\mathrm{ABD}$, çok sayıda sözleşmeli personeli Irak'ta konuşlandırabilmiştir. 2009 yılı sonrası verilerin ayrıntılı bir şekilde bulunabildiği raporlarda 2009-2018 yılları arasında ABD Savunma Bakanlı̆̆ı, Tablo 2'de görülebileceği üzere özel askeri ve güvenlik şirketleriyle yaklaşı 104 milyar dolarlık sözleşme imzalamıştır (Peters \& Plagakis, 2019: 1). 2009-2016 yılları arası ABD’nin Irak'ta bulunmasının maliyeti ortalama 303 milyar dolar civarındayken ABD'nin aynı dönem için imzaladığı sözleşme bedelleri, yaklaşık 90 milyar dolar civarında olmuştur.

2009 y1lı öncesiyle ilgili ayrıntılı veriler olmasa da 2003-2008 yılları arasında özel askeri ve güvenlik şirketleri ile Bush yönetimi arasındaki işbirliği önemli boyutlara ulaşmış ve bu dönemde ABD, Afganistan ve Irak'ta özel şirketlerle 60 milyar dolar civarına ulaşan sözleşmeler imzalamıştır (Satz, 2013: 1000). ABD, 2003-2007 yılları arası lojistik hizmetlerinin karşılanması için özel şirketlerle 22 milyar dolarlık sözleşme imzalayarak 
yiyecek ve yakıt tedariki ile geçici üslerin inşası gibi hizmetleri tamamen özel sektöre devretmiştir (Avant \& Sigelman, 2010: 233). 2003 yılı sonrası AEGIS Defence Services şirketi, 293 milyon dolar (Ortiz, 2010: 37), Vinnell Corporation, 48 milyon dolar, (Zabc1, 2003: 40) CACI, 66.2 milyon dolar (Dickinson, 2010: 221), İngiltere merkezli Halliburton şirketi ise 3.9 milyar dolar değerinde sözleşmeleri, Pentagon ile imzalayarak Irak’ta ABD ile işbirliğine başlamıştır. Benzer bir şekilde ABD merkezli Blackwater şirketi, 2003 yılında 27 milyon dolarlık sözleşme bedeliyle Irak pazarına girerken taraflar arasında artan işbirliği sonucunda 2008 yılına kadar Blackwater ile imzalanan sözleşmelerin toplam bedeli, 1 milyar doların üstüne çıkmıştır (Scahill, 2008: 12). Tablo 2'de görüldüğü üzere ABD, Irak’tan 2011 yılında çekilmesine rağmen 2011 yılı sonrasında da özel askeri ve güvenlik şirketleriyle yüksek bedelli sözleşmeler imzalamaya devam etmiş ve bu şirketler yoluyla çok sayıda sözleşmeli personeli Irak’ta konuşlandırabilmiştir.

Tablo 2

ABD Savunma Bakanlı̆̆ı'nın 2009-2018 Yılları arası İmzaladığı Sözleşme Bedelleri (milyon dolar)

\begin{tabular}{|c|c|c|c|}
\hline Yll & Sözleșme Bedeli & Yll & Sözleşme Bedeli \\
\hline 2009 & $\$ 21.933$ & 2014 & $\$ 5.944$ \\
\hline 2010 & $\$ 18.267$ & 2015 & $\$ 7.330$ \\
\hline 2011 & $\$ 12.661$ & 2016 & $\$ 6.720$ \\
\hline 2012 & $\$ 7.079$ & 2017 & $\$ 7.039$ \\
\hline 2013 & $\$ 9.156$ & 2018 & $\$ 7.852$ \\
\hline \multicolumn{2}{|c|}{ Toplam } & $\mathbf{1 0 3 . 9 8 0}$ \\
\hline
\end{tabular}

Kaynak: Peters, H. M., \& Plagakis, S. (2019). Department of defense contractor and troop levels in Iraq and Afghanistan: 2007-2018. Washington, the USA: Congressional Research Service, 17.

\section{İnsani Maliyetlerin Dışsallaştırılması}

ABD yönetimleri açısından sözleşmeli personelin Irak’ta yoğun bir şekilde kullanılmasının bir diğer sebebi, artan insani maliyetler olmuştur. ABD’nin Irak’taki mevcudiyeti uzadıkça insan kaynağı ihtiyacı artmaya başlamış, fakat Irak’ta bulunmanın artan maliyetleri sonucunda insan kaynağı sözleşmeli personel üzerinden sağlanmıştır. Irak'ta sözleşmeli personel sayıları her geçen yıl artmış ve hatta bazı yıllarda bu sayı, askeri personel sayısını aşmıştır. Irak Savaşı'nın başladığı tarih olan 2003 yılında 140.000 askeri personele 21.000 sözleşmeli personel eşlik ederken (Avant, 2006: 330), Bush yönetiminin Irak Savaşı'nın insani yükünü dışsallaştırmaya çalışmasının doğrudan sonucu olarak sözleşmeli personel sayısı, 2006 yılında 100.000 civarına ulaşmıştır (Avant, 2007: 457). 2007 yılının sonunda 165.607 ABD askeri personeline karşılık 154.825 sözleşmeli personel Irak’ta yer almış (bkz: Tablo 3) ve bir yıl gibi kısa bir zaman içerisinde Irak’taki sözleşmeli personel sayısı yüzde 50 civarında artmıştır. 2009 yılının başında 148.500 ABD askeri personeline 148.050 sözleşmeli personel eşlik ederek askeri personel ve sözleşmeli personel arasındaki fark ortadan kalkmıştır (Peters \& Plagakis, 2019: 13). Ayrıca Irak’ta bulunan özel güvenlik alanında faaliyet gösteren personeli sayısı, 2008 yılından 2010 yılına kadar geçen süre zarfında 6.000'den 11.030 'a ${ }^{5}$ çıkarak

52010 yılı baz alındığında özel güvenlik personeli, sözleşmeli personel içerisindeki en büyük ikinci grup olmuştur. 2010 yılında ABD’nin Irak’taki sözleşmeli personelinin \%65'i askeri üs desteğinin sağlanması, $\% 8$ 'i çevirmenlik, \%4'ü lojistik, \%2'si taşıma, \%1'i iletişim, \%1'i eğitim ve \%12'si güvenlik alanlarında faaliyet göstermiştir. McFate, S. (2014). The modern mercenary: private armies and what they mean for world order. New York, the USA: Oxford University Press. 
hemen hemen ikiye katlanmıştır (Krahmann, 2013: 60). Sözleşmeli personelin büyük bir kısmının ABD dışından karşılanmasıyla insani maliyetler daha da dışsallaştırılabilmiştir. Örneğin Tablo 3'te görüldüğü üzere Irak Savaşı'nın en hareketli yıllarından biri olan 2008 yılında Irak'ta görev alan sözleşmeli personel sayısı 163.591 iken bu sayının sadece 31.325'i ABD'li personelden oluşmuştur. Benzer bir şekilde 2008 yılında Irak’ta özel güvenlik alanında faaliyet gösteren 9.952 personelin sadece 830 'u ABD vatandaşlarından oluşmuştur. Geriye kalan personel, üçüncü ülke veya Irak üzerinden sağlanmıştır (Peters \& Plagakis, 2019: 13-16). Benzer bir durum 2011 yılı sonrası dönemde de devam etmiş ve örneğin 2013 yılında 8.449 sözleşmeli personelin 6.093'ünü üçüncü ülke vatandaşları ve Iraklılar oluştururken özel güvenlik alanındaki 2.281 personelinin sadece 235 'i ABD vatandaşlarından oluşmuştur.

Tablo 3

Irak'ta Yer Alan ABD’li Askeri Personel, Sözleşmeli Personel ve Özel Güvenlik Personeli Sayıları

\begin{tabular}{|c|c|c|c|c|c|c|c|}
\hline YIL & $\begin{array}{c}\text { Askeri } \\
\text { Personel } \\
\text { Sayısı }\end{array}$ & $\begin{array}{c}\text { Sözleşmeli } \\
\text { Personel } \\
\text { Sayısı }\end{array}$ & $\begin{array}{c}\text { ABD'li } \\
\text { Sözleşmeli } \\
\text { Personel } \\
\text { Sayısı }\end{array}$ & $\begin{array}{c}\text { Yabancı } \\
\text { ve Ev } \\
\text { Sahibi Ülke } \\
\text { Sözleşmeli } \\
\text { Personel } \\
\text { Sayısı }\end{array}$ & $\begin{array}{c}\text { Özel } \\
\text { Güvenlik } \\
\text { Alanında } \\
\text { Faaliyet } \\
\text { Gösteren } \\
\text { Sözleşmeli } \\
\text { Personel } \\
\text { Sayısı }\end{array}$ & $\begin{array}{c}\text { Özel } \\
\text { Güvenlik } \\
\text { Alanında } \\
\text { Faaliyet } \\
\text { Gösteren } \\
\text { ABD'li } \\
\text { Sözleşmeli } \\
\text { Personel } \\
\text { Sayısı }\end{array}$ & $\begin{array}{c}\text { Özel } \\
\text { Güvenlik } \\
\text { Alanında } \\
\text { Faaliyet } \\
\text { Gösteren } \\
\text { Yabancı } \\
\text { ve Ev } \\
\text { Sahibi Ülke } \\
\text { Vatandaşı } \\
\text { Sözleşmeli } \\
\text { Personel } \\
\text { Sayısı }\end{array}$ \\
\hline 2007 & 165.607 & 154.825 & 26.869 & 127.956 & Bilgi yok & Bilgi yok & Bilgi yok \\
\hline 2008 & 161.783 & 163.591 & 31.325 & 132.266 & 9.952 & 830 & 9.122 \\
\hline 2009 & 148.500 & 148.050 & 39.262 & 108.788 & 9.218 & 727 & 8.436 \\
\hline 2010 & 114.300 & 100.035 & 27.843 & 72.192 & 11.095 & 776 & 10.319 \\
\hline 2011 & 47.305 & 71.142 & 19.943 & 51.199 & 8.327 & 791 & 7.536 \\
\hline 2012 & 11.445 & 23.886 & 11.237 & 12.649 & 8.995 & 751 & 8.244 \\
\hline 2013 & ---- & 8.449 & 2.356 & 6.093 & 2.281 & 235 & 2.046 \\
\hline 2014 & ---- & 3.234 & 820 & 2.414 & Bilgi yok & Bilgi yok & Bilgi yok \\
\hline 2015 & 3.550 & 1.349 & 1.140 & 209 & 43 & Bilgi yok & Bilgi yok \\
\hline 2016 & 3.550 & 2.028 & 1.392 & 636 & 118 & Bilgi yok & Bilgi yok \\
\hline 2017 & 5.262 & 3.592 & 2.035 & 1.557 & 370 & Bilgi yok & Bilgi yok \\
\hline 2018 & Bilgi yok & 4.927 & 2.767 & 2.160 & 406 & Bilgi yok & Bilgi yok \\
\hline
\end{tabular}

Kaynak: Peters, H. M., \& Plagakis, S. (2019). Department of defense contractor and troop levels in Iraq and Afghanistan: 2007-2018. Washington, the USA: Congressional Research Service, 13-16.; Office of the Assistant Secretary of Defense for Sustainment (n.d.), CENTCOM: Quarterly Contractor Census Reports. Alınan yer https:// www.acq.osd.mil/log/PS/CENTCOM_reports.html

\section{Siyasi Maliyetlerin Dışsallaştırılması}

Irak Savaşı'nın Bush yönetimine getirdiği bir diğer önemli maliyet, siyasi maliyettir. ABD'nin Irak'taki mevcudiyetinin uzaması hem ABD ve uluslararası kamuoyunda hem de ABD’nin siyasi arenasında Bush yönetimine yeni maliyetler getirmiştir. Özellikle ABD kamuoyundaki Irak Savaşı'yla ilgili memnuniyetsizlik her geçen sene artmıştır. 2003 yılında Amerikan kamuoyunun sadece \%23'ü Irak’a müdahaleyi yanlış bulurken 
bu oran, 2008 y1lında \%63'e yükselmiştir (Dugan, 2013). Sonraki y1llarda müdahalenin yanlış olduğunu düşünenlerde azalma olsa dahi bu oran \%50'nin üzerinde kalmaya devam etmiş ve hiçbir zaman 2003 yılındaki orana gerilememiştir. ABD’nin Irak'a müdahalesi 2008 yılında icra edilen başkanlık yarışının da önemli bir konusu olmuş ve seçim öncesi Demokrat Parti adayı Barack Obama, ABD’nin Irak’taki varlığını eleştirirken kendisi seçilmesi halinde Irak’tan çekilme sözü vermiştir (Obama, 14 Temmuz 2008). Barack Obama, başkan seçildikten sonra da Bush döneminin yanlışlarının düzeltileceğini vurgulamış ve bölgeye karşı görece daha realist bir yaklaşım sergilemiştir (Gerges, 2013: 299). Fakat her ne kadar ABD, Obama döneminde Irak'tan çekilse de kitle imha silahlarının yayılması ve terörizm konuları, Bush döneminde olduğu gibi temel tehditler olarak tanımlanmaya devam etmiş (Obama, 2010: 19-24) ve bu tehditlerle mücadelede güç kullanımı önemini korumuştur. Trump döneminde de Obama dönemine benzer tehdit tanımlamaları devam etmiş ve tehditlere karşı güç kullanımı konusunda bu dönemde de radikal bir değişiklik olmamıştır. Trump yönetimi de Obama yönetimi gibi maliyetli askeri müdahalelerden uzak durmayı hedeflese de gerektiğinde tehditlere karşı güç kullanımı konusunda Obama’ya benzer bir yaklaşım sergilemiştir (Trump, 2017: 10-11). $\mathrm{Bu}$ yüzden ABD’nin çeşitli başkanları açısından Irak’taki savaşın siyasi maliyetlerinin dışsallaştırılması önemli olurken sözleşmeli personel, 2011 öncesi ABD ordusunun 'yanında' 2011 yılı sonrasında ise ağırlıklı olarak ABD ordusunun 'yerine' kullanılmış ve bu yolla Bush sonrası dönemde siyasi maliyetler sözleşmeli personelle dışsallaştırılmıştır.

ABD yönetimleri açısından siyasi maliyetleri düşüren bir diğer önemli nokta, özel askeri ve güvenlik şirketleri üzerindeki sınırlı kongre denetimi olmuştur. ABD yönetimleri, sözleşmeli personel yoluyla yasamanın kontrolünden kaçabilmiş (Avant, 2004: 155) ve kongre denetimine bağlı olmayan özel askeri ve güvenlik şirketleri aracılığıyla çok sayıda sözleşmeli personeli Irak’ta görevlendirebilmiştir. Yürütmenin yasamanın önünde olması, bu şirketlerin demokratik denetimi konusunda soru işaretleri doğursa da (Abrahamsen \& Williams, 2007: 137) özel şirketlerin kullanımı, ABD yönetimlerini kongre denetiminin yanında belirli ölçülerde kamuoyu baskısından da kurtarmıştır. Sözleşmeli personelin kullanımı insani maliyetlerin dışsallaştırılmasına yardımcı olduğu için belirli ölçülerde siyasi maliyetlerinin dışsallaştırılmasına da yardımcı olmuştur (Yıldız \& Ekmekçioğlu, 2018: 34). ABD ordusunda meydana gelen zayiatlar, ABD kamuoyuyla şeffaf bir şekilde resmi yollarla paylaşılırken sözleşmeli personelin yaşadığı ölüm ve yaralanmalar, ABD kamuoyu ile paylaşılmamış ve ABD medyasında geniş yer bulmamıştır. Bu yolla ABD'nin gerçekte yaşadığı zayiatlar olduğundan düşük gösterilebilmiş ve zayiatların özel şirketler aracılığıyla dışsallaştırılması belirli ölçülerde kamuoyundaki tepkiyi de sınırlandırmıştır. ${ }^{6}$

\section{Özel Askeri ve Güvenlik Şirketleri ve Sözleşmeli Personelin Sebep Olduğu Sorunlar}

Özel askeri ve güvenlik şirketleri, 2003 yılı sonrası Irak’ta çok sayıda tartışmanın merkezinde olurken bu şirketler ve sözleşmeli personel hem ABD hem Irak açısından önemli soruna sebep olmuştur. Özel şirketler ve sözleşmeli personel, ABD açısından

6 Deborah Avant ve Lee Sigelman'ın yaptığı araştırmaya göre ABD kamuoyu, Irak'ta ölen özel askeri ve güvenlik şirketi çalışanlarına ve yabancı uyruklu çalışanlara karşı ABD askerlerine benzer bir şekilde hassasiyet gösterse de sözleşmeli personel zayiatlarının ABD medyası ve siyasi çevrelerde yeteri kadar yer bulmaması, ABD kamuoyundaki tepkiyi sınırlandırıcı bir etkiye sebep olmuştur. Araştırmanın ayrıntıları için bkz: Avant, D. \& Sigelman L. (2010). Private security and democracy: lessons from the US in Iraq. Security Studies, 19(2), 230-265. 
Irak’taki insani, ekonomik ve siyasi maliyetleri belirli ölçüde dışsallaştırmış görünse de diğer taraftan kısa ve uzun dönemli yeni maliyetler yaratmıştır. Özel şirketlerin ve sözleşmeli personelin ABD ordusuyla iyi tanımlanmamış ilişkisi, ABD’ye Irak’ta yeni sorunlara yol açarken özel şirketlerin sebep olduğu insan hakları ihlalleri, çatışmaların içerisinde yer alması ve güvenliğin piyasalaşmasına dolaylı yoldan sebep olması, süreç içerisinde ön plana çıkan diğer önemli sorunlar olmuştur.

\section{ABD’nin Özel Askeri ve Güvenlik Şirketleri ve Sözleşmeli Personelle Yaşadığı Sorunlar}

ABD yönetimlerinin Irak’ta yoğun bir şekilde özel askeri ve güvenlik şirketlerini devreye sokması, özellikle çatışma sahalarında önemli sorunlara yol açmıştır. Özel askeri ve güvenlik şirketlerinin, koalisyon güçleri için yarattı̆̆1 en büyük sorun, taraflar arasındaki koordinasyon ve entegrasyon sorunu olmuştur (Avant, 2007: 458). Özel şirketlerin, Irak'ta taşeron yöntemiyle iş görmesi koalisyon güçleri ile şirketlerin koordinasyonunu bir taraftan daha zor hale getirirken özel askeri ve güvenlik şirketlerinin ABD'nin komutası altında olmayıp ABD ile ortaklık ilişkisine sahip olması (Welch, 2009: 353) ve sözleşmeli personelin askeri komutaya tâbi olmaması (Percy, 2009: 63) çatışma alanlarındaki koordinasyonu daha sorunlu hale getirmiştir. Ayrıca ABD ordusunun savaş alanlarında şirketlere emir verme yetkisinin olmaması (Wulf, 2005: 58) ve her iki aktörün farklı emir komuta sistemlerine tâbi olmaları, iki güç arasındaki entegrasyonu engellemiştir. Örneğin taraflar arasındaki koordinasyon sorunu ve özel şirketlerin görev alanlarının belirsizliği yüzünden 2004 yılında Felluce'de 4 Blackwater çalışanı öldürüldüğünde askeri yetkililerin bölgedeki Blackwater'ın faaliyet alanlarından dahi habersiz olduğu iddia edilmiştir. 2009 yılına kadar taraflar arasındaki koordinasyon sorunu önemini korumuş (Perry, 2012: 43) ve çatışma alanlarında önemli sorunlar yaratmaya devam etmiştir.

Sözleşmeli personelin Irak’ta yoğun bir şekilde kullanılması, belirli dönemlerde ABD adına insan kaynağı ihtiyacı açısından da sorunlar yaratmıştır. Sözleşmeli personelin çatışmaların tırmandığı dönemlerde sözleşmelerini feshetmeleri, çatışma sahasındaki planların uygulanmasinda sorunlara sebep olurken (Wulf, 2005: 58) ayrilan personelin yerine yeni personel bulma ihtiyacını da doğurmuştur. Güvenliğin piyasalaşması, ABD ordusu açısından başka ek sorunlar da yaratmış ve özellikle kalifiye personel için özel askeri ve güvenlik şirketleri önemli bir çekim merkezi haline gelmiştir. Kalifiye personel, askeri veya sivil bürokraside bir yılda kazanabileceği ücretleri, özel şirketlerde bir ayda kazanma firsatı yakalamış ve hatta bu şirketler, kalifiye personel için yılda 200.000 dolara kadar ulaşabilen ücretler ödemiştir (Krahman, 2012: 352). Bu şartlar altında kalifiye personel için özel şirketler ön plana çıkarken ABD ordusu için insan kaynağı adına ek sorunlar meydana gelmiştir.

\section{Özel Askeri ve Güvenlik Şirketlerinin İnsan Hakları İhlalleri}

Özel askeri ve güvenlik şirketlerinin Irak’ta sebep olduğu en büyük sorunlardan biri insan hakları ihlalleri olmuştur. 2003-2011 yılları arasında Irak’ta faaliyet gösteren 89 özel askeri ve güvenlik şirketinin $15^{\prime}$ 'inin insan hakları ihlallerinde bulunduğu tespit edilmiş ve Irak merkezli olmayan bu şirketler, toplam $46 \mathrm{kez}$ insan hakları ihlalinde bulunmuştur. $\mathrm{Bu}$ dönemde Irak merkezli özel askeri ve güvenlik şirketleri de $3 \mathrm{kez}$ insan hakları 
ihlalinde bulunmuştur (Palou-Loverdos \& Armendariz, 2011: 49). Sözleşmeli personelin sebep olduğu ihlaller, özel şirketlerin Irak’taki rolleri açısından önemli tartışmalara sebep olurken aynı zamanda Irak'ta ve uluslararası toplumda önemli tepkiler doğurmuştur. ABD ile sözleşmeye sahip şirketlerin Irak’ta sebep olduğu işkence, keyfi tutuklamalar gibi insan hakları ihlallerinin cezasız kalması ise ABD'nin ününe zarar vermiş ve Irak’ta ABD karşıtı görüşlerin yükselmesine sebep olmuştur.

ABD'nin Irak’ta bulunduğu süre zarfında sözleşmeli personelin en bilinir insan hakları ihlalleri, Irak hapishanelerinde yaşanmıştır. Irak’taki hapishanelerde mahkumların sözleşmeli personel tarafından geniş çaplı işkencelere ve cinsel istismara maruz kaldığı ortaya çıkarken özel askeri ve güvenlik şirketlerinin isimleri, mahkumlara yapılan işkence ve kötü muamelede bolca geçmiştir. 2003 yılında Ebu Gureyb hapishanesinde en az 72 Irak vatandaşının sorgulamaları sırasında zihinsel ve fiziksel kötü muamele gördükleri ve işkenceye uğradıkları ortaya çıkmış (Palou-Loverdos \& Armendariz, 2011: 53) ve CACI ve Titan şirketlerinin çalışanlarının bu ihlallerde yer aldığı belirtilmiştir (Perry, 2012: 48). Ebu Gureyb hapishanesinde yaşanan insan hakları ihlalleri, Irak ve uluslararası kamuoyunda yoğun tepkiye sebep olsa da insan hakları ihlallerinde adı geçen CACI şirketi, yaptıkları araştırma sonucunda CACI şirketinin kusuru olmadığını açıklamıştır (Welch, 2009: 359). Özel askeri ve güvenlik şirketleri ile çalışanlarının Irak yasalarına karşı dokunulmazlıklarının olması (Isenberg, 2010: 88), insan hakları ihlallerine adı karışanların yargılanmasını engellerken sözleşmeli personelin uluslararası insancıl hukuka göre muharip olarak tanımlanmaması ve uluslararası kamu hukukunun ve uluslararası özel hukukun dışında kalmaları (Tangör \& Yalçınkaya, 2010: 148) uluslararası hukuk açısından yargılanmalarının önünde engel oluşturmuştur (De Nevers, 2009: 171). Sözleşmeli personelin ulusal ve uluslararası hukuk açısından gri alanda bulunmaları (Wenger \& Mason, 2008: 841) sebebiyle 2008 yılına kadar hiç bir sözleşmeli personel, işledikleri suçlar yüzünden yargılanamazken (Scahill, 2008: 8) ilerleyen yıllarda bu sözleşmeli personelin hukuki belirsizlikleri önemli bir tartışma konusu olmaya devam etmiştir. Ebu Gureyb'deki gibi insan hakları ihlallerinin cezasız kalması ise hem özel şirketlerin rolleri hakkında soru işaretleri doğurmuş hem de Irak’taki ABD karşıtı akımların yükselmesine uygun zemin sağlamıştır. Sözleşmeli personelin insan hakları ihlalleri ve işledikleri suçlar ayrıca Iraklı (The Iraqi Civil Society Solidarity Initiative, n.d.) ve uluslararası sivil toplum kuruluşlarının (Global Policy Forum, n.d.) önemli tepkilerine yol açmıştır.

\section{Özel Askeri ve Güvenlik Şirketlerinin Şiddetle İlişkisi}

Özel askeri ve güvenlik şirketleri ve sözleşmeli personel, Irak’ta hem şiddetin hedefi hem de şiddetin faili olarak Irak’taki şiddetin tırmanmasına dolaylı da olsa etki etmiştir. Irak’ta özel güvenlik alanındaki sözleşmeli personeli sayısı, Eylül 2007'den Haziran 2009'a kadar geçen sürede \% 140 artmış ve bu personelin yaklaşı \% $\% 88$ 'ini silahlı personel oluşturmuştur (Franke \& Von Boemcken, 2011: 726-727). Bir başka ifadeyle, Irak’ta çatışmaların yoğunlaştığı 2007-2009 yılları arasında sözleşmeli personel açısından özel güvenlik personeli ve hatta silahlı özel güvenlik personeli ön plana çıkmıştır.

ABD kuvvetlerinin yanında yer alan sözleşmeli personel, 2003 yılı sonrası Irak’taki grupların ‘yabancı' ve ‘işgalci’ güçlere karşı uyguladıkları şiddetten doğrudan etkilenmiş 
ve Irak’ta sözleşmeli personel sayıları arttıkça yaralanan, öldürülen veya kaçırılan sözleşmeli personel sayısı da her geçen yıl artmış ve hatta 2010-2014 yılları arasında hayatını kaybeden sözleşmeli personel sayısı, hayatını kaybeden ABD askeri sayısının üzerine çıkmıştır. Sözleşmeli personel sayılarının 2008 yılı öncesi kayıt altına alınmaması ve sözleşmeli personelin ölüm ve yaralanmalarının açıklanmaması, bu aktörlerin maruz kaldığ içerisinde sadece Blackwater şirketinden en az 25 kişinin öldürüldüğü tahmin edilmektedir (Fainaru, 20 Eylül 2007: 17). 4 Blackwater personelinin Felluce'de öldürülmesi sonras1 Nisan 2004'te ABD'nin Felluce'ye başlattığı geniş kapsamlı operasyon, Irak'ta 1. Felluce Muharebesi'ne yol açarken (Hills, 2006: 623) aynı zamanda ülke içerisinde ABD'ye karşı oluşan ayaklanmanın en temel sebeplerinden biri olmuştur (Fontan, 2006: 217218). Aynı yıl Irak'ın diğer bölgelerinde yaşanan ayaklanmalarda da sözleşmeli personel sıcak çatışmaların tarafı olmuştur. Necef Muharebesi olarak bilinen koalisyon güçleri ile Mehdi ordusu arasında yaşanan çatışmalara özel askeri ve güvenlik şirketleri doğrudan taraf olmuştur. Benzer bir şekilde 2004 yılında Kut kentinde Hart Group çalışanları, ayaklanmacılarla sıcak çatışmaya girerken (Avant, 2005: 233) Nisan 2004'te Necef'de ABD karargahına düzenlenen saldırılara Blackwater şirketi karşılık vermiştir. Sadece ArmorGroup şirketinin konvoy güvenliği sırasında 2006 yılında 450, 2007 yılının ilk 4 ayında ise 293 saldırıya ve düşmanca eyleme maruz kaldığı belirtilmiştir (Fainaru, 16 Haziran 2007: 12). 4 Crescent Security Group çalışanın Irak’taki İslami Direniş Örgütü tarafından kaçırılması (Fainaru, 30 Temmuz 2007: 10) ve 2009 yılında El Kaide'nin 2 Blackwater çalışanını öldürmesi (Perry, 2012: 47) gibi olaylar, sözleşmeli personelin Irak'ta aktif silahlı devlet dişı aktörlerin uyguladığı şiddetten etkilendiğini gösteren diğer örneklerdir.

Tablo 3'te görülebileceği üzere sözleşmeli personelin sayısının her yıl artması, ABD askerlerinin yerine kullanılması ve çatışma ve risk içeren bölgelerde aktif rol almalarının doğrudan sonucu olarak sözleşmeli personelin maruz kaldığ 1 şiddet her geçen yıl artmıştır. 2003 yılında sözleşmeli personelin yaşadığı ölümler, ABD'nin kayıplarının sadece \%4'ü oluştururken bu oran 2004-2007 yılları arasında \%27'e 2008-2010 yılları arasında ise \%40'a ulaşmıştır (McFate, 2014: 23). Irak’ta Kasım 2005'e kadar 428 sözleşmeli personelin öldürüldüğü 3963'ünün ise yaralandığı tahmin edilmektedir (Isenberg, 2010: 84). 2007 yılına kadarsa 1123 sözleşmeli personelin öldüğü (Percy, 2009: 63) ve 12000 civarında da personelin yaralandığ 1 tahmin edilmektedir. Aynı dönem göz önüne alındığında, Irak’ta ölen ABD askeri sayısının 4000 civarı olduğu belirtilmektedir (Godfrey, Brewis, Grady \& Grocott, 2014: 119). Bir diğer ifadeyle, 2003-2007 y1lları arası ABD güçleri tarafinda ölen her beş kişiden biri sözleşmeli personel olmuştur (Taylor, 2011: 450). ABD’nin Irak'tan çekilme kararı alması sonrasında da sözleşmeli personel, ülke içi şiddetten etkilenmeye devam etmiş ve hatta 2010 yılı sonrası dönemde sözleşmeli personel açısından ortaya çıkan zayiatlar, ABD ordusundakinden fazla olmuştur. 20102014 yılları arası baz alındığında Irak’ta 117 askere karşılık 156 sözleşmeli personel hayatını kaybederken yaralanan 603 askeri personele karşılık, yaralanan sözleşmeli personel sayısı 16.058 olmuştur (University of Denver, n.d.). Sözleşmeli personelin büyük çoğunluğunun yabancı uyruklu veya Iraklı olmasının doğrudan sonucu olarak (bkz: Tablo 3) ölüm ve yaralanmalardan $A B D$ vatandaşı sözleşmeliler daha az etkilenmiştir. Benzer bir durum kaçırılma olaylarında da görülmüş ve sadece 2003-2006 yılları arasında 165 
yabancı uyruklu sözleşmeli personel, ${ }^{7}$ farklı gruplar tarafından kaçırılmıştır (O’Hanlon \& Campbell, 2009: 53).

Sözleşmeli personel, Irak’ta şiddet uygulayan aktörlerin de başında gelmiş ve bu şirketlerin insan hakları ihlallerinin büyük bir kısmı, yetkilerinin dışında şiddet kullanımından doğmuştur. 2005 yılında Blackwater şirketinin özel askeri ve güvenlik şirketlerinin kullanmaları yasak olan CS gazını kullandığına dair şüpheler, 2006 yılında Triple Canopy şirketi çalışanlarının konvoy güvenliği sırasında sivil araçlara ateş açması (Fainaru, 15 Nisan 2007: 20), Crescent Security Group şirketinin tanksavar gibi askeri düzenlemeler çerçevesinde özel şirketlerin sahip olması yasaklanmış silahlara sahip olduğunun tespit edilmesi (Fainaru, 29 Temmuz 2007: 14), Unity Resources Group şirketinin çalışanlarının konvoy güvenliği sırasında 2 Iraklı sivilin ölümüne sebep olması (Kramer \& Glantz, 10 Ekim 2007), Şubat 2006'da Blackwater çalışanlarının Kerkük’te üç sivili öldürmesi (Fainaru, 24 Aralık 2007: 10), Blackwater personelinin Irak başkan yardımcısının korumasını öldürmesi, 2007 yılında Blackwater'ın keskin nişancısının 3 mağaza güvenliğini öldürmesi, Iraklı gazetecinin özel şirket çalışanları tarafından öldürülmesi, Ernys şirketi çalışanlarının sivil araca ateş açması (Palou-Loverdos \& Armendariz, 2011: 50), Blackwater çalışanlarının Bağdat'ta açtığı ateş sonrası bir Irak vatandaşının ölmesi (Welch, 2009: 354) gibi çok sayıda hukuk dişı ve şiddet içeren eylem, özel şirketlerin Irak’ta şiddetin tırmanmasındaki rollerini göstermesi açısından önemli örneklerdir. Bu örneklerin yanında özel şirketlerin ülkedeki güvensizliğe ve şiddete etkilerinin en açık ve popüler örneklerinden biri, Eylül 2007'de yaşanmış ve Nisur Meydanı'nda yaşanan olaylar, Irak ve ABD arasında yeni sorunlara yol açarken uluslararası toplumda da özel askeri ve güvenlik şirketlerinin rolleri ve hukuki durumları hakkında önemli tartışmalara sebep olmuştur. 16 Eylül 2007'de 17 sivilin Bağdat'ın Nisur Meydanı'nda Blackwater çalışanlarının açtığı ateş sonucunda ölmesi, Irak'ta "Kanlı Pazar" olarak tanımlanan olaylara sebep olmuştur (McFate, 2014: 59). Nisur Meydanı'nda yaşananların araştırılması sonucu Blackwater tarafından açılan 17 ateşin en az 14'ünün gerekçesiz olduğu belirtilmiş ve şirketin açtığ 1 ateşin şiddet kullanımı açısından ABD yasalarına aykırı olduğuna kanaat getirilmiştir (Franke \& Von Boemcken, 2011: 728729). Nisur Meydanı'nda şiddet uygulayan Blackwater çalışanlarının uluslararası hukuk açısından sorumlu tutulamaması (Cohn, 2011: 381-382) ve Irak yasaları yerine ABD yasalarına göre yargılanması, ABD ile Irak arasındaki ilişkileri germiştir. Irak hükümetinin şirketin Irak’taki faaliyetlerini sona erdirmesi talebine karşılık Blackwater şirketinin ilerleyen yıllarda yeniden Irak’ta faaliyeti başlaması, özel şirketlerin denetimi konusunda yeni tartışmaları da beraberinde getirmiştir.

İnsan hakları ihlalleri ve şiddet kullanımı konusunda Blackwater şirketi en bilindik şirket olsa da ABD ile önemli sözleşmelere sahip DynCorp ve Triple Canopy gibi şirketler de ülkedeki şiddet ve güvensizlik ortamına doğrudan etki etmiştir. Nisur Meydanı'nda yaşananlardan sonra yapılan kongre araştırmasına göre Blackwater şirketinin yanında

7 2003-2006 yılları arasında toplam 439 yabancı Irak’ta kaçırılırken, kaçırılma olaylarına en çok maruz kalan yabancılar, sözleşmeli personel olmuş ve 165 yabancı uyruklu sözleşmeli personel kaçırılmıştır. Aynı dönem göz önüne alındığında sadece 15 yabancı uyruklu diplomat veya hükümet çalışanı ve 6 yabancı uyruklu askeri personel kaçırılmıştır. 2003-2006 yılları arasında Irak’ta farklı gruplar tarafından kaçırılan yabancı uyrukluların mesleki dağılımı için bkz: The New York Times (2006, 16 Mayıs). Foreign victims of kidnappings in Iraq. Alınan yer https://archive.nytimes.com/www.nytimes.com/imagepages/2006/05/16/ opinion/17hostages.html?action=click\&module=RelatedCoverage\&pgtype=Article\&region=Footer 
DynCorp ve Triple Canopy şirketlerinin de sıcak çatışmalara taraf oldukları ve bu çatışmaların çoğunda ilk ateş açan taraf oldukları ortaya çıkmıştır. Yapılan araştırma sonucu sadece 2005-2007 yılları arası Blackwater şirketinin 195 sicak çatışmaya girdiği ve 195 çatışmanın \%80'den fazlasında ilk ateş eden taraf olduğu, (Congress of the United States House of Representatives, 2007: 1-2) Triple Canopy şirketinin 36 sıcak çatışmanın içerisinde yer aldığ 1 ve bu çatışmaların 30'unda ilk ateş eden taraf olduğu ve DynCorp'un ise girdiği 102 sıcak çatışmanın 63'ünde ilk ateş açan taraf olduğu tespit edilmiştir. Bu şirketlerin dişında Unity Resources Group, Eryns, USIS şirketlerinin de Irak’ta sıcak çatışmalarda çatışmayı başlatan taraflar oldukları ortaya çıkmış ve bu çatışmalarda sivillerin ölümlerine sebep oldukları tespit edilmiştir. (Palou-Loverdos \& Armendariz, 2011: 54).

\section{Şiddetin ve Güvenliğin Özelleşmesinin Irak’taki Sonuçları}

ABD’nin sözleşmeli personel üzerinden Irak savaşının ekonomik, insani ve siyasi maliyetlerini dışsallaştırmaya çalışması, 2003 yılı sonrası çok sayıda insan hakları ihlalinin, şiddetin tırmanmasının ve ABD ordusuna çatışma sahasında yeni sorunlar yaratmasının yanında güvenliğin özelleşmesi açısından da uzun vadede sorunlara sebep olmuştur. ABD’nin Irak'a özel güvenlik kavramını ihraç etmesi, güvenlik anlayışının piyasalaşmasına sebep olmuştur. Geleneksel güvenlik kurumları, genelde çatışma alanlarında savunma, savaş, ölüm-kalım ve çatışmayı kazanma gibi kavramlar üzerinden motive olurken, özel şirketler için temel motivasyon kaynağı kâr ve ticari kazanç olmuştur (Wulf, 2005: 57). Diğer bir ifadeyle geleneksel güvenlik anlayışında planlamalar, 'en kötü senaryo' varsayımı üzerine kurgularken, şirketler 'en az maliyet' üzerine güvenlik stratejileri üretmiş ve en az maliyet anlayışı, güvenliğin piyasalaşmasına sebep olmuştur.

Güvenlik kavramının piyasalaşması, sözleşmeli personelin ücretlendirilmelerinde açıkça görülmektedir. Irak’taki sözleşmeli personelin yaklaşık yarısı Iraklılardan oluşurken geriye kalan personelin dörtte biri gelişmiş, dörtte biri ise gelişmekte olan ülkelerden oluşmuştur (Spearin, 2007: 542). Şirketlerin insan kaynağını Irak veya gelişmekte olan ülkelerden sağlamasının temel motivasyonlarından biri ise maliyetleri düşürmek olmuştur (Joachim \& Schneiker, 2012: 503). İngiltere ve ABD gibi ülkelerden sağlanan kalifiye personel, şirketlerin pazarlamasında ön plana çıkarttıkları grup olsa da Irak ve üçüncü ülkelerden sağlanan personelle şirketlerin maliyetleri düşürülmüştür (Avant, 2006: 334). Vatandaşlık temelinde ücretlendirme ile şirketlerin maliyet ilişkisi, çalışanlara verilen maaşlar üzerinden gözlemlenebilmektedir. İngiliz veya Amerikalı personel için aylık 10.000 dolara kadar çıkabilen ücretler, Şilili personel için 4000, Salvadorlu personel için 1700, Güney Afrikalılar içinse 5000 dolar civarında seyretmiştir (Spearin, 2007: 542). Ücretler, Hindistan, Nepal, Sri Lanka, Pakistan ve Filipinler gibi daha az gelişmiş ülkelerin vatandaşları söz konusu olduğunda daha da düşmüş ve bu ülkelerden sağlanan üçüncü ülke vatandaşlarının ücretleri, Batılı bir kalifiye personelin ücretinin yirmide birinden daha az olmuştur (Ekmekçioğlu, 2016; 107).Irak’taki sözleşmeli personelin yaklaşık yarısını oluşturan Iraklılar ise özel güvenlik piyasasından en az yararlanabilen gruplardan biri olmuş ve Iraklıların ücretleri 1000 dolar civarında seyretmiştir (Hammer, 2008).Güvenliğin piyasalaşması milliyet üzerinden görüldüğü kadar çatışma üzerinden de gözlemlenebilmektedir. Özel askeri ve güvenlik şirketleri, çatışmaların yoğun olduğu bölgelerde görev alanlar için aylık 2000 dolara varan ek ücretler ödeyebilirken (Franke 
\& Von Boemcken, 2011: 728) ülkede şiddetin azaldığı dönemlerde ücretlerde 1000-2000 dolar civarında kesintiye gitmiştir.

ABD kongresinin 2008 yılından itibaren özel askeri ve güvenlik şirketleri üzerindeki denetimi arttırmaya başlaması, 2008 yılında kabul edilen Montreux belgesinin ${ }^{8}$ uluslararası hukuk açısından özel askeri ve güvenlik şirketlerinin ve bu şirketlerle ilişkili devletlerin (International Committee of the Red Cross, 2009: 9) faaliyetlerini düzenlemeye çalışması ve BM'nin özel güvenlik şirketleri tarafından sağlanan silahlı ve silahsız güvenlik hizmetlerinin kullanımına yönelik k1lavuzu (Krahmann \& Leander, 2019: 174) gibi ulusal ve uluslararası girişimler, özel askeri ve güvenlik şirketlerinin hak ve sorumluluklarının belirlenmesi açısından önemli gelişmeler olmuştur. Özel askeri ve güvenlik şirketlerinin sebep olduğu insan hakları ihlalleri ve taraf olduğu şiddet olayları sonrası ABD kongresi sözleşmeli personel ve özel şirketler üzerindeki denetimi arttırarak Irak örneğinde olduğu gibi pratikten doğan sorunları sınırlandırmaya çalışmıştır. Montreux belgesi ise özel askeri ve güvenlik şirketleriyle sözleşme imzalayan devletler, şirketlerinin bağlı olduğu devletler ve bu şirketlerin faaliyet gösterdiği devletler (DeWinter-Schmitt (ed.), 2013: 7-8) için bağlayıcı olmayan tavsiyelerde bulunarak uluslararası düzlemde özel askeri ve güvenlik şirketlerine hukuki ve normatif bir çerçeve çizmeye çalışmıştır. ${ }^{9}$ Bir başka ifadeyle, hem bireysel olarak devletler hem de uluslararası toplum, özel askeri ve güvenlik şirketleriyle ilgili ortaya çıkan sorunların üstesinden gelmeye çalışmaktadır. Gerek 1990 sonrası hızla büyüyen özel güvenlik piyasası gerekse devletler, uluslararası şirketler, sivil toplum kuruluşları, BM gibi uluslararası örgütler ve hatta bireylerin (Erkmen, 2019: 5) yoğun bir şekilde özel askeri ve güvenlik şirketlerinin hizmetlerinden faydalanmaları, bu şirketlerin ulusal ve uluslararası güvenlik açısından önemlerinin artarak devam edeceğini göstermektedir. 1990 yılında 55.6 milyar dolar (Yılmaz, 2007: 45) olan özel güvenlik piyasasının 2011 yılında 120 milyar doların üstüne çıkması, 2018 yılında 205.5 milyar dolara ulaşması ve 2024 yılında 248.1 milyar dolara ulaşacağının öngörülmesi (Market Watch,18 Haziran 2019) özel güvenlik anlayışının küresel ölçekte büyüyerek kabul gördüğünü göstermektedir (Abrahamsen \& Williams, 2011: 173-174). Bu yüzden denetlenen, şeffaf ve hukuken sınırlandırılmış olan özel askeri ve güvenlik şirketleri, savaşın çeşitli maliyetlerinin dışsallaştırılması açısından önümüzdeki dönemde önemini korumaya devam edecektir.

Fakat özel askeri ve güvenlik şirketleriyle ortaya çıkan tartışmalar sadece pratikten doğan sorunlar değildir. Özellikle güvenliğin piyasalaşmasında özel askeri ve güvenlik şirketlerinin rolü, güvenlik anlayışının dönüşümünde önem arz etmektedir. Bu şirketler aracılığıyla güvenliğin özelleşmesi ve satın alınabilir bir hizmet haline dönüşmesi, kamu

82008 yılında ortaya çıkan Montreux belgesi, 17 ülke tarafından kabul edilirken bu 17 ülke içerisinde özel askeri ve güvenlik şirketlerinin bolca tartışıldığı ABD, İngiltere, Afganistan ve Irak gibi ülkeler bulunmaktadır. Bugün itibariyle Montreux belgesine taraf olan devlet sayısı 56, uluslararası örgüt sayısı ise üçtür. Montreux belgesine taraf olan aktörler için bkz: Federal Department of Foreign Affairs-FDFA (2019). Participating States of the Montreux Document. Alınan yer https://www.eda.admin.ch/eda/en/home/foreignpolicy/international-law/international-humanitarian-law/private-military-security-companies/participatingstates.html

9 Montreux belgesinin uygulanmasında özellikle Irak ve Afganistan gibi kırılgan ülkelerde daha fazla sorunlar çıkmaktadır. Montreux belgesindeki prensiplerin ABD, Birleşik Krallık, Irak ve Afganistan'daki uygulamalarını görmek ve bu ülkeleri karşılaştırmak için bkz: DeWinter-Schmitt, R. (Ed.) (2013). Montreux five years on: an analysis of state efforts to implement Montreux document legal obligations and good practices. Washington, the USA: Washington College of Law and Novact. 
güvenliğini olumsuz etkileme potansiyeline sahip olmakta ve güvenliğin dışlayıcı bir hale gelmesine sebep olmaktadır (Krahmann \& Leander, 2019: 176-177). 2003 yılı sonrası Iraklılar için ülkedeki en temel kaygı güvenlik konusu olurken (Fontan, 2006: 217) güvenliğin Irak’ta ABD aracılığıyla özelleştirilmesi, bu temel kaygının ortadan kalkmasını engellemiştir. Irak gibi kırılgan bir ülkede güvenliğini satın alamayan kitlelerin güvenlik ihtiyacını devlet dışı aktörlerle karşılama riski ortaya çıkmaktadır. Güvenliğin dışlayıcı bir hale gelmesi ise yukarıdan aşağıya özelleşme eğilimlerini kuvvetlendirdiği kadar aşağıdan yukarıya özelleşme eğilimlerini de kuvvetlendirmektedir. Bir başka ifadeyle, Irak’ta güvenliğin ABD eliyle özelleşmesi sonucu Irak’taki aktörler, güvenlikleri için özel askeri ve güvenlik şirketlerinin yanında silahlı devlet dışı aktörlere veya milis güçlerine başvurmaya başlamıştır. Bu ise Irak içerisinde güvensizlik sarmalına ve dolaylı da olsa şiddetin artmasına sebep olmuştur.

\section{Sonuç}

9/11 sonrası ABD’nin Afganistan ve Irak’a terörle mücadele çerçevesinde yaptığ askeri müdahaleler, ABD, Afganistan ve Irak siyasetleri ve uluslararası ilişkiler açısından önemli kırılmalara sebep olmuştur. 2003 yılında ABD’nin Irak'a müdahalesi ve 2011 yılına kadar Irak'ta bulunması, başta Bush yönetimi olmak üzere ABD yönetimlerine önemli maliyetlere sebep olmuştur. ABD'nin Irak’ta bulunduğu süre zarfinda savaşın ekonomik, insani ve siyasi maliyetleri her geçen yıl artmıştır. Irak savaşının sadece 2008 yılındaki ekonomik maliyeti 197 milyar dolar civarında olurken aynı yıl Irak'ta bulunan ABD askeri sayısı, 161,783'e yükselmiştir. 2008 yılında ayrıca ABD kamuoyunun \%63'ü Irak'a yapılan askeri müdahaleyi yanlış bulmuştur. 2003 yılı sonrası Irak Savaşı'nda ABD’nin her yıl artan ekonomik, insani ve siyasi maliyetleri, bu savaşın maliyetlerinin dışsallaştırılmasını önemli hale getirmiş ve bu dışsallaştırma sürecinde özel askeri ve güvenlik şirketleri ile bu şirketler üzerinden sağlanan sözleşmeli personel ön plana çıkan aktörler olmuştur. Her ne kadar bu aktörler, savaşın maliyetlerinin tümünün dışsallaştırılmasına yardımcı olmasa da bu aktörler sayesinde daha düşük sözleşme bedelleriyle ABD'li askeri personel sayısından daha fazla sözleşmeli personel Irak'ta görevlendirilmiştir. Bush dönemi sonrasında da sözleşmeli personel ve özel şirketler önemini korumaya devam etmiş ve Obama ve Trump dönemlerinde bu aktörler, Irak'ta ABD tarafından kullanılmaya devam etmiştir.

Sözleşmeli personelin ve özel şirketlerin Irak’ta farklı yönetimler tarafından savaş sırasında veya sonrası dönemde kullanılması, bazı maliyetlerin belirli ölçülerde dışsallaştırılmasına sebep olsa da sözleşmeli personelin sebep olduğu sorunlar, ABD ve Irak açısından öngörülemeyen yeni maliyetler yaratmıştır. Özel askeri ve güvenlik şirketlerinin ABD ordusuyla yaşadığı koordinasyon sorunu ABD açısından önemli sorunlara sebep olsa da bu şirketlerin Irak’ta şiddete maruz kalması ve şiddete başvuran aktörlerin başında gelmesi belirli ölçülerde Irak içerisindeki şiddetin tırmanmasına etki etmiştir. Sözleşmeli personelin yaygın bir şekilde sebep olduğu insan hakları ihlalleri, Irak’ta Amerikan karşıtlığına etki ederken aynı zamanda uluslararası toplumda önemli tartışmalara sebep olmuştur. Sözleşmeli personelin Irak’ta görevlendirilmesinde kongre denetiminin sınırlı olması yürütmeye güç kullanımı konusunda daha fazla imkan tanırken sözleşmeli personelin uluslararası ve ulusal hukuk açısından belirsiz durumları, 
yeni tartışmaları beraberinde getirmiştir. Montreux belgesi gibi uluslararası girişimler, özel askeri ve güvenlik şirketleri ile bu şirketlerle ilişkili devletler arasındaki ilişkileri düzenlemeye çalışsa da Irak ve Afganistan gibi kırılgan ülkelerde özel şirketlerin denetimi ve faaliyetleri hala önemli sorun olmaya devam etmektedir.

Güvenliğin ve şiddetin özelleşmesinin pratikteki sorunlarının ötesinde Irak özelinde güvenlik piyasasının ortaya çıkması yeni sorunları beraberinde getirmiştir. Piyasa dinamikleri üzerinden Irak gibi kırılgan bir ülkede güvenlik kavramı belirli ölçülerde kamu malı olmaktan çıkıp satın alınabilen bir hizmete dönüşmüştür. Güvenliği satın alamayan kitleler ise bazen silahlı devlet dışı aktörlerle kendi güvenliklerini sağlamaya çalışmıştır. Bir başka ifadeyle, Irak’ta şiddetin yukarıdan aşağıya ve aşağıdan yukarıya özelleşme biçimleri iç içe geçmiş ve birbirini etkilemiştir. Kısaca Irak’ta güvenlik ve şiddetin özelleşmesi, Irak’ta ulusal güvenlik kavramına dolaylı da olsa zarar vermiştir.

Hakem Değerlendirmesi: Dış bağımsız.

Çıkar Çatışması: Yazar çıkar çatışması bildirmemiştir.

Finansal Destek: Yazar bu çalışma için finansal destek almadığını beyan etmiştir.

Peer-review: Externally peer-reviewed.

Conflict of Interest: The author has no conflict of interest to declare.

Grant Support: The author declared that this study has received no financial support.

\section{Kaynakça/References}

Abrahamsen, R., \& Williams, M. C. (2007). Selling security: assessing the impact of military privatization. Review of International Political Economy, 15(1), 131-146.

Abrahamsen, R., \& Williams, M. C. (2011). Security privatization and global security assemblages. The Brown Journal of World Affairs, 18(1), 171-180.

Albayrak, G. (2013). Uluslararası hukukta hedef alarak öldürme. İstanbul: On İki Levha Yayıncılık.

Amadeo, K. (2019). Cost of Iraq war: timeline, economic impact. Balance. Alınan yer https:/www.thebalance. com/cost-of-iraq-war-timeline-economic-impact-3306301

Avant, D., \& Sigelman L. (2010). Private security and democracy: lessons from the US in Iraq. Security Studies, 19(2), 230-265.

Avant, D. (2004). The privatization of security and change in the control of force. International Studies Perspectives, 5(2), 153-157.

Avant, D. (2005). The market for force: the consequences of privatizing security. New York: Cambridge.

Avant, D. (2006). The privatization of security, lessons from Iraq. Orbis, 50(2), 327-342.

Avant, D. (2007). Contracting for services in US military operations. PS: Political Science \& Politics, 40(3), $457-460$.

Brooks, D. (2000). Messiahs or mercenaries? the future of international private military services. International Peacekeeping, 7(4), 129-144.

Cohn, L. P. (2011). It wasn't in my contract: security privatization and civilian control. Armed Forces \& Society, 37(3), 381-398.

Congress of the United States House of Representatives (2007). Memorandum: additional information about blackwater USA.

De Nevers, R. (2009). Private security companies and the laws of war. Security Dialogue, 40(2), 169-190.

DeWinter-Schmitt, R. (Ed.) (2013). Montreux five years on: an analysis of state efforts to implement Montreux document legal obligations and good practices. Washington: Washington College of Law and Novact.

Dickinson, L. A. (2010). Contract as a toll for regulating private military companies. İçinde Simon Chesterman \& Chia Lehnardt (Eds.), From mercenaries to market: the rise and regulation of private military companies (ss. 217-238). New York, the USA: Oxford University Press.

Dugan, A. (2013). On 10th anniversary, 53\% in U.S. see Iraq War as mistake. Gallup. Alınan yer http://news. gallup.com/poll/161399/10th-anniversary-iraq-war-mistake.aspx

Yıldız, M. ve Ekmekçioğlu, A. (2016). Özel askeri şirketlerin savunma politikaları açısından incelenmesi. Amme Idaresi Dergisi, 51(3), 27-59.

Ekmekçioğlu, A. (2016). Savaşın virüsler: özel askeri şirketler. Ankara: Nobel Yayın. 
Erkmen, S. (2019). Silahlı güçler; ordular, para-militer yapılar, özel askeri şirketler. Uluslararası İlişkiler Konseyi: Güvenlik Yazları, 39, 1-7.

Fainaru, S. (2007, 15 Nisan). A chaotic day on Baghdad's airport road. The Washington Post, s. 20.

Fainaru, S. (2007, 16 Haziran). Iraq contractors face growing parallel war. The Washington Post, s. 12.

Fainaru, S. (2007, 19 Eylül). Where military rules don't apply. The Washington Post, s. 17.

Fainaru, S. (2007, 24 Aral1k). Warnings unheeded on guards in Iraq. The Washington Post, s. 10.

Fainaru, S. (2007, 29 Temmuz). Cutting costs, bending rules, and a trail of broken lives. The Washington Post, s. 14.

Fainaru, S. (2007, 30 Temmuz). For abducted guards, Iraq wasn't just about money. The Washington Post, s. 10.

Federal Department of Foreign Affairs-FDFA (2019). Participating States of the Montreux Document. Alinan yer https://www.eda.admin.ch/eda/en/home/foreign-policy/international-law/international-humanitarianlaw/private-military-security-companies/participating-states.html

Fontan, V. (2006). Polarization between occupier and occupied in post-Saddam Iraq: colonial humiliation and the formation of political violence. Terrorism and Political Violence, 18(2), 217-238.

Franke, V., \& Von Boemcken M. (2011). Guns for hire: motivations and attitudes of private security contractors. Armed Forces \& Society, 37(4), 725-742.

Gerges, F. A. (2013). The Obama approach to the Middle East: the end of America's moment? International Affairs, 89(2), 299-323.

Global Policy Forum (n.d.). PMSC in Iraq. Alınan yer https://www.globalpolicy.org/pmscs/50154-iraq.html

Godfrey, R., Brewis, J., Grady, J., \& Grocott, C. (2014). The private military industry and neoliberal imperialism: mapping the terrain. Organization, 21(1), 106-125.

Hammer, J. (2008). Blackwater blues: hard times for mercenaries in Iraq. The New Republic. Alınan yer https:// newrepublic.com/article/63673/blackwater-blues

Hills, A. (2006). Fear and loathing in Falluja. Armed Forces and Society, 32(4), 623-639.

International Committee of the Red Cross (2009). The Montreux Document: on pertinent international legal obligations and good practices for states related to operations of private military and security companies during armed conflict. Geneva, Switzerland.

Isenberg, D. (2010). A government in search of cover: private military companies in Iraq. İçinde Simon Chesterman \& Chia Lehnardt (Eds.), From mercenaries to market: the rise and regulation of private military companies (ss. 82-93). New York: Oxford University Press.

Jervis, R. (2009). Unipolarity: A structural perspective. World Politics, 61(1), 188-213.

Joachim, J., \& Schneiker A. (2012). Of 'true professionals' and 'ethical hero warriors': a gender-discourse analysis of private military and security companies. Security Dialogue, 43(6), 495-512.

MacAskill, E., \& Borger, J. (2004, 16 Eylül). Iraq war was illegal and breached UN charter, says Annan. The Guardian. Alınan yer https://www.theguardian.com/world/2004/sep/16/iraq.iraq

Market Watch (2019, 18 Temmuz). At 3.8\% CAGR, global private security service market size to exceed \$248.1 million by 2024. Alınan yer https://www.marketwatch.com/press-release/at-38-cagr-global-privatesecurity-service-market-size-to-exceed-2481-million-by-2024-2019-07-18

Mearsheimer, J. J. (2011). Imperial by design. The National Interest, 111, 16-34.

NATO (2015, 1 Eylül). NATO and the 2003 campaign against Iraq (archived). Alınan yer https://www.nato.int/ cps/en/natohq/topics_51977.htm

Krahmann, E. \& Leander A. (2019). Contracting security: markets in the making of MONUSCO peacekeeping. International Peacekeeping, 26(2), 165-189.

Krahmann, E. (2012). from 'mercenaries' to 'private security contractors': the (re)construction of armed security providers in international legal discourses. Millennium-Journal of International Studies, 40(2), 343-363.

Krahmann, E. (2013). The United States, PMSCs and the state monopoly on violence: Leading the way towards norm change. Security Dialogue, 44(1), 53-71.

Kramer, A. E., \& Glantz J. (2007, 10 Ekim). U.S. guards kill 2 Iraqi women in new shooting. The New York Times. Alınan yer https://www.nytimes.com/2007/10/10/world/middleeast/10iraq.html

Krieg, A. (2016). Externalizing the burden of war: the Obama doctrine and US foreign policy in the Middle East. International Affairs, 92(1), 97-113.

Mandel, R. (2001). The privatization of security. Armed Forces \& Society, 28(1), 129-151.

McFate, S. (2014). The modern mercenary: private armies and what they mean for world order. New York: Oxford University Press.

Nuruzzaman, M. (2015). President Obama's Middle East policy, 2009-2013. Insight Turkey, 17(1), 171-190.

O’Hanlon, Michael E. \& Campbell, Jason H. (2019). Iraq index:tracking variables of reconstruction \& security in post-Saddam Iraq. the USA: Brookings.

Obama, B. (2008, 14 Temmuz). My plan for Iraq, The New York Times. Alınan yer https://www.nytimes. com/2008/07/14/opinion/14obama.html

Obama, B. (2010). National security strategy of the United States-2010. Washington: The White House.

Office of the Assistant Secretary of Defense for Sustainment (n.d.), CENTCOM: Quarterly Contractor Census Reports. Alınan yer https://www.acq.osd.mil/log/PS/CENTCOM_reports.html

Ortiz, C. (2010). The new public management of security: the contracting and managerial state and the private military industry. Public Money \& Management, 30(1), 35-41. 
Palou-Loverdos, J., \& Armendariz L. (2011). The privatization of warfare, violence and private military \& security companies: a factual and legal appraoch to human right abuses by PMSC in Iraq. Barcelona, Spain: Nova- Social Innovation.

Peltier, I. J. (2005). Surrogate warfare: the role of US army special forces. Kansas, The USA: Army Command and General Staff Coll Fort Leavenworth KS School of Advanced Military Studies.

Percy, S. (2009). Private security companies and civil wars. Civil Wars, 11(1), 57-74.

Percy, S. (2012). Regulating the private security industry: a story of regulating the last war. International Review of the Red Cross, 94(887), 941-960.

Perry, D. (2012). Blackwater vs. bin Laden: the private sector's role in American counterterrorism. Comparative Strategy, 31(1), 41-55.

Peters, H. M., \& Plagakis, S. (2019). Department of defense contractor and troop levels in Iraq and Afghanistan: 2007-2018. Washington: Congressional Research Service.

Satz, D. (2013). Markets, privatization and corruption. A Social Research: An International Quarterly, 80(4), 993-1008.

Scahill, J. (2008). Blackwater: the rise of the world's most powerful mercenary army. New York: Nations Book.

Simpson, G. (2005). The war in Iraq and international law. Melb. J. Int'l L., 6, 167-188.

Singer, P.W. (2002). Corporate warriors: the rise of the privatized military industry and its ramifications for international security. International Security, 26(3), 186-220.

Spearin, C. (2007). Contracting a counterinsurgency? implications for US policy in Iraq and beyond. Small Wars and Insurgencies, 18(4), 541-558.

Tangör, B., \& Yalçınkaya, H. (2010). Güvenlik yönetişimi çerçevesinde özel askeri şirketler. Uluslararası İlişkiler, 7(25), 127-154.

Taylor, T. (2011). Private security companies in Iraq and beyond. International Affairs, 87(2), 445-456.

The Bureau of Investigative Journalism (n.d.). Drone strikes in Afghanistan. Alınan yer https://www. thebureauinvestigates.com/projects/drone-war/afghanistan

The Guardian (2003, 22 Ocak). France and Germany unite against Iraq war. Alınan yer https://www.theguardian. com/world/2003/jan/22/germany.france

The Iraqi Civil Society Solidarity Initiative-ICSSI (n.d.). Stop Private Military Companies. Alınan Yer https:// www.iraqicivilsociety.org/archives/category/thematic-issues/stop-private-military-companies.

Trump, D. (2017). National security strategy of the United States -2017. Washington: The White House.

University of Denver (n.d.). Statistics on the private security industry. Alınan yer http://psm.du.edu/articles reports_statistics/data_and_statistics.html

Welch, M. (2009). Fragmented power and state-corporate killings: A critique of blackwater in Iraq. Crime, Law and Social Change, 51(3-4), 351-364.

Wenger, A., \& Mason S. JA. (2008). The civilianization of armed conflict: Trends and implications. International Review of the Red Cross, 90(872), 835-852.

Wulf, H. (2005). Internationalizing and privatizing war and peace. Hampshire: Palgrave Macmillan.

Wulf, H. (2011). The privatization of violence: a challenge to state-building and the monopoly on force. The Brown Journal of World Affairs, 18(1), 137-149.

Yılmaz, S. (2007). 21'inci yüzyılda güvenlik alanının yeni sivil aktörleri: özel askerî şirketler ve kontratçı firmalar. Güvenlik Stratejileri Dergisi, 3(6), 43-70.

Zabcı, F. Ç. (2003). Yeni savaşların gizli yüzü: Özel askeri şirketler. Mülkiye, 28(243), 24-37. 
